\title{
Farmer Breeding Objectives and Production Constraint of Arsi Cattle Reared in Mid Rift Valley of Oromia
}

Received: 27 October, 2020

Accepted: 10 December, 2020

Published: 11 December, 2020

*Corresponding author: Aman Gudeto, Oromia Agriculture Research Institute (IQQO), Adami Tulu Agriculture Research Center, B.O.Box 35, Batu, Ethiopia, Email: amangude13@gmail.com

Keywords: Cattle production constraints; Arsi cattle; Breeding objectives; Mid rift valley

https://www.peertechz.com

\section{Check for updates}

\author{
Aman Gudeto $^{1 *}$, Sandip Banerjee ${ }^{2}$ and Tadele Mirkena ${ }^{3}$ \\ 1Oromia Agriculture Research Institute (IQQO), Adami Tulu Agriculture Research Center, B.O.Box 35, \\ Batu, Ethiopia \\ ${ }^{2}$ Mansarovar Global University, College of Agriculture Science and Technology, India \\ ${ }^{3}$ Food and Agriculture Organization of United Nation (FAO), Addis Ababa, Ethiopia
}

\begin{abstract}
The study was conducted in mid-rift valley of Oromia Regional State of Ethiopia with objective to assess traditional cattle breeding objectives and their production constraints. Adami Tulu Jidokombolcha (ATJK), Bora, Dodola, Shala and Negele-Arsi were purposely selected from East Shoa and West Arsi Zones which found in the Oromia Region. The two hundred forty respondents were selected based on random sampling procedures. The main of age and family size of the respondents were 43.1 years and 8.9, respectively. Survey result revealed that family size were higher in Shala where the poly marriage practice was more common than others districts. Cattle population per house hold were higher in Shala while sheep population were higher in Dodola and Bora districts. Goat size were higher in Negele-Arsi, ATJK and Shala districts. Furthermore, finding showed that farmers were reared cattle mainly for draft, milk, risk aversion and income source. The survey result indicated that feed shortage, water scarcity, disease and shortage of improved genotype were the major cattle production constraints in the studied districts. However water shortage was not secondarily critical in Dodola district. Forage improvement, water conservation, disease prevention and improving genetic potential of cattle is needed to solve the main livestock production constraint to improve the livelihood of small holder farmers. c
\end{abstract}

\section{Introduction}

Ethiopia has large livestock populations with cattle estimated at about 59.48 million heads [1]. The majority of these cattle (98.2\%) are native breeds/ecotype, with miniscule numbers of animals being crossbred and exotic animals. Livestock contribute significantly to the livelihoods of small holder farmers and the pastoralists. Cattle provide for rearers draught power, milk, manure and cash [2]. They also play a significant role in the sociocultural and socioeconomic values of the society. Beside the importance of cattle among the agrarian communities and to the national economy system at large, this sector has remained underdeveloped and in many cases underutilized [3].

Farmers have traditionally learn to identify and conserve their valuable genetic resources through traditional breeding systems. Their consideration of genetic values varies across communities. For instance, Mursi cattle are reared primary for milk production in pastoral community of southern Ethiopia [4]. However, Horro cattle are reared primary for draught power in western part of Oromia, Ethiopia [5].

The country has huge potential for increasing cattle production, both for local use and for export purposes. Even so, there are different cattle production constraints in the Ethiopia. The shortages of feed and water are some of the primordial constraints that have also been reported by Asrat, et al. [6] from South part of Ethiopia. Deficient and unbalanced nutriment, disease outbreak, scarcity of water and incompetent information to improve animal performances were major problems in the country [7]. Prioritization of the production constraints is important as it help to use scarce resources efficiently. In any cattle production system, to undertake 
intervention for improvement of productivity of livestock and design breeding programme, it is essential to identify the constraints that hinder the production and purpose of keeping cattle. However, information on the purpose of keeping the Arsi cattle and its production constraints in the study areas is scanty. Therefore, the study was aimed to assess the traditional objective of keeping the cattle and address their production constraints in selected districts Figure 1.

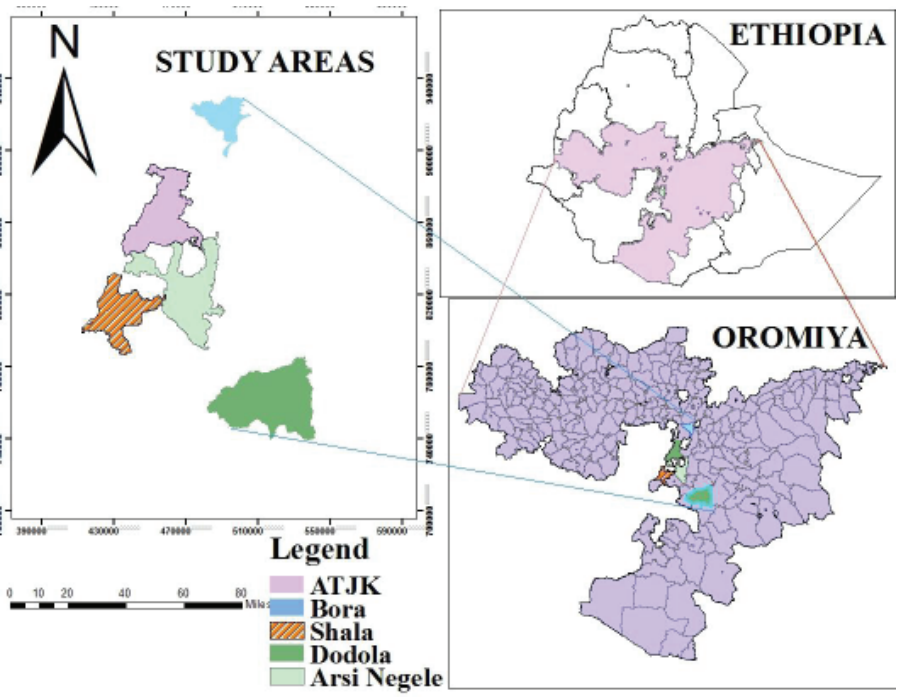

Figure 1: Map of study districts.

\section{Materials and methods}

\section{Description study areas}

Sampling methods: Multistage purposive sampling technique was employed for the selection of study districts and kebeles. East Shoa and West Arsi Zones were selected from mid rift valley of Oromia Regional state of Ethiopia. Again ATJK and Bora from East Shoa Zone and Dodola, Shala and NegeleArsi from West Arsi Zone were selected based on potential of Arsi cattle. The samples were proportionate according to the total numbers of farmers per district. Accordingly, total of 240 households/farmers/ were randomly selected and interviewed. Family size, livestock possession, breeding objectives and cattle production constraints were collected the developed questionnaire.

\section{Data analysis}

Data gathered during the study period was checked for any error, coded and entered into excel spreadsheet. The general linear model of social package statistical software version 24 was used to analyse quantitative data. Indices were done for cattle production purpose and livestock production constraints as following:

$$
\text { Index }=\frac{R n * \mathrm{C} 1+\mathrm{Rn}-1 * \mathrm{C} 2 \ldots+\mathrm{R} 1 * \mathrm{Cn}}{\Sigma R n * \mathrm{C} 1+\mathrm{Rn}-1 * \mathrm{C} 2 \ldots+\mathrm{R} 1 * \mathrm{Cn}}
$$

Where $\mathrm{Rn}$ = value given for the least ranked level (example if the least rank is $5^{\text {th }}$, then $\mathrm{Rn}=5, \mathrm{Rn}-1=4$, and ..., R1=1), $\mathrm{Cn}=$ count of the least ranked level (in the above level example, the count of the $5^{\text {th }}=\mathrm{Cn}$, and the count of the $1^{\text {st }}$ rank $=\mathrm{C} 1$ ). The opposite matching for $\mathrm{R}$ and $\mathrm{C}$ values can be presented as follows: R1 for Rn; R2 for Rn-1...; Rn for R1 and C1 for Cn; C2 for Cn-1; ... ; Cn for C1. Source [8].

\section{Results and Discussions}

\section{Age and family size of the respondents}

The age and family sizes of the respondents are presented in Table 1 . There were differences $(P<0.05)$ in family sizes among the respondents in the selected districts. The family sizes were larger in Shala district while the reverse was true with intermediate values across the other districts. The mean age of the respondents were similar to those reported by Getachaw, et al. [9] from Moretna Jiru district of Amhara Region. The study indicated that there were differences in the family size which will has consequence on the overall profit of the farm [10]. This is because the larger the family size the lesser will be the overall per unit share from the agrarian activities [11] The overall family size as observed in this study are similar to what was reported by Zemene, et al. [12] from the Jimma Zone and Emana, et al. [13] from Gambella Region of Ethiopia. The respondents may have an inclination to have a large family size as this can give them additional farm hands in agrarian activities. However, over the period of time larger family size could result in fragmentation of farm hand which can have negative consequences over time [11].

\section{Livestock possession among the respondents}

The livestock possessions of the respondents in the study areas are summarized in Table 2 . The results indicate that the numbers of cattle reared per household are varied across the study areas, which can be attributed to the importance of cattle in the overall farming economy; availability of farm lands year round and inputs [14]. The results indicated that the dependence on cattle husbandry is higher in Shala because of higher incidences of crop failure in the past. The numbers of sheep were higher in the highlands while the numbers of goats were higher at the lowlands which can be ascribed to their adaptability to the agro-ecologies [5].

\section{Purpose of keeping livestock across the study areas}

The findings presented in Table 3 indicate that cattle are primarily kept as a source of draft power and milk, in all the

Table 1: Age and family size (Mean \pm S. D) of the respondents in study areas.

\begin{tabular}{|c|c|c|}
\hline District & Age $(\mathbf{y r})$. & Family size (No) \\
\hline ATJK & $46.2 \pm 10.8$ & $9.1 \pm 3.3^{\mathrm{b}}$ \\
\hline Bora & $42.7 \pm 14.7$ & $6.5 \pm 2.8^{\mathrm{a}}$ \\
\hline Dodola & $43.4 \pm 10.1$ & $9.6 \pm 4.1^{\mathrm{bc}}$ \\
\hline Shala & $40.2 \pm 10.2$ & $10.6 \pm 3.7^{\mathrm{c}}$ \\
\hline Negele-Arsi & $42.8 \pm 14.2$ & $8.3 \pm 3.4^{\mathrm{b}}$ \\
\hline Overall & $43.1 \pm 12.2$ & $8.9 \pm 3.7$ \\
\hline
\end{tabular}

Notes: yr: years; No: Numbers; ${ }^{a, b, c} P<0.05$ values across columns are different 
Table 2: Livestock possession in the sampled households.

\begin{tabular}{|c|c|c|c|c|c|c|}
\hline & & District & & & & \\
\hline Species & ATJK & Bora & Dodola & Shala & Negele-Arsi & Overall \\
\hline Cattle & $12 \pm 0.8^{b}$ & $8.6 \pm 1.4^{a}$ & $11.8 \pm 1^{b}$ & $13.7 \pm 1.1^{c}$ & $10 \pm 0.8^{\mathrm{ab}}$ & $11.1 \pm 0.5$ \\
\hline Sheep & $0.2 \pm 0.03^{a}$ & $0.7 \pm 0.2^{b}$ & $0.5 \pm 0.1^{b}$ & $0.1 \pm 0.02^{\mathrm{a}}$ & $0.1 \pm 0.02^{\mathrm{a}}$ & $0.3 \pm 0.1$ \\
\hline Goat & $0.7 \pm 0.4^{b}$ & $0.1 \pm 0.03^{a}$ & $0.2 \pm 0.3^{a}$ & $0.7 \pm 0.1^{\mathrm{b}}$ & $0.6 \pm 0.1^{\mathrm{b}}$ & $0.5 \pm 0.1$ \\
\hline
\end{tabular}

ATJK: Adami Tulu Jidokombolcha; TLU: Tropical Livestock Unit; Conversion factors were: 0.7 for cattle, 0.1 for sheep and goats, $(F A 0,2002)$ a, b, $(P<0.05)$ values across the rows are different

Table 3: Purpose of cattle rearing in the studied areas.

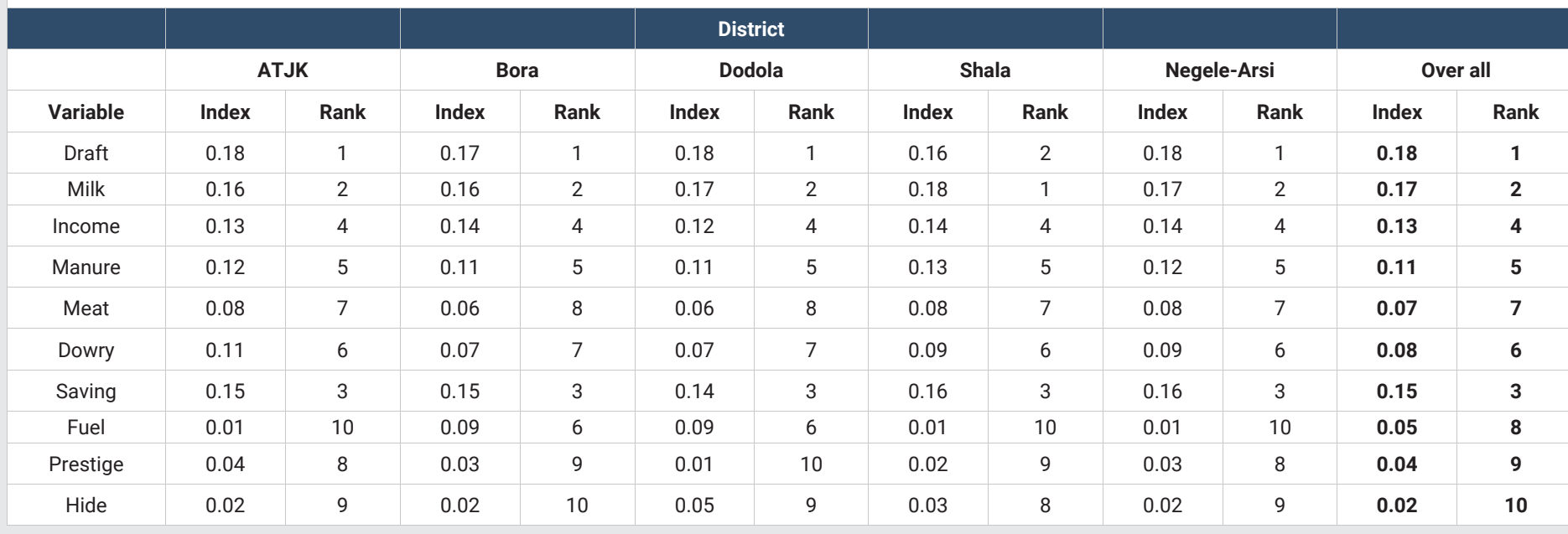

studied locations except in Shala district where milk was the primary cattle breeding goal. The results furthermore indicated that cattle are raised as a source of savings and serve as a source of income in all the studied locations. This is in accordance with the findings of Shiferaw [15] from Fantale District East Shoa Zone and Endashaw, et al. [4] from southern west Ethiopia. The main purpose of rearing cattle in the study areas is for draft reported by Belay, et al. [16] from central parts of Ethiopia. This might be because the cattle are the major source of draft power for all sorts of agrarian activities viz. ploughing, threshing, carrying inputs and outputs from the farm land. The cows are raised primarily as a source of milk and also dairy products such as butter and cottage cheese. Cattle are also the major source of farm input in form of the manure.

\section{Cattle production constraints}

Major production constraints of the cattle reared in the study areas are summarized in Table 4. The results indicated that feed followed by water shortages in the area were some of the major constraints faced by the respondents in this study. The shortages of feed and water are some of the primordial constraints that have also been reported by Asrat et al., [6] from South part of Ethiopia and Solomon, et al. 2014 [17] from North West part of Ethiopia. However, diseases are second most important cattle production constraint in Bench Maji Zone, southwestern Ethiopia [18]. The availability of feed and water both in quality and quantity are important for livestock development in the area. Thus, the livestock development agents need to appraise the respondents about the conservation of forage and water in the area [19].
Index $=\mathrm{Rn}{ }^{*} \mathrm{C} 1+\mathrm{Rn}-1 * \mathrm{C} 2 \ldots+\mathrm{R} 1 * \mathrm{Cn} / \mathrm{Rn} * \mathrm{C} 1+\mathrm{Rn}-1 \ldots+\mathrm{R} 1 * \mathrm{Cn} ;$ Where $\mathrm{Rn}=$ value given for the least ranked level (example if the least rank is 5 th, then $\mathrm{Rn}=5, \mathrm{Rn}-1=4$, and ..., R1=1), $\mathrm{Cn}=$ count of the least ranked level (in the above level example, the count of the 5th = Cn, and the count of the 1st rank = C1). The opposite matching for $\mathrm{R}$ and $\mathrm{C}$ values can be presented as follows: R1 for Rn; R2 for Rn-1...; Rn for R1 and C1 for Cn; C2 for $\mathrm{Cn}-1 ; \ldots$; Cn for $\mathrm{C} 1$.

The respondents need to be trained in post-harvest conservation of crop residues besides proper feeding and utilization [20]. The study further indicated other constraints as diseases and less genetic potential of the cattle, which too are in close accordance with those of Kebede, et al. [21]. As diseases are one of the major problems in livestock development in the country [13], prevention of diseases through proper management of the livestock are important for the holistic improvement of the sector [5]. Thus, besides identification and prevention of economically important diseases in the area, the development agents need to appraise the respondents about vaccination of livestock. Moreover, many of the respondents complained about improving the genetic stock among the livestock in the area. Thus, the artificial insemination program has to be improved for rapid genetic improvement in the area as suggested by Hunduma [22]. To make the artificial insemination program successful proper estrus detection and management of cattle both pre and post insemination must be taken into account [23].

\section{Conclusion and Recommendation}

The respondents had large family sizes which may correlate 
Table 4: Livestock production constraint in the studied areas.

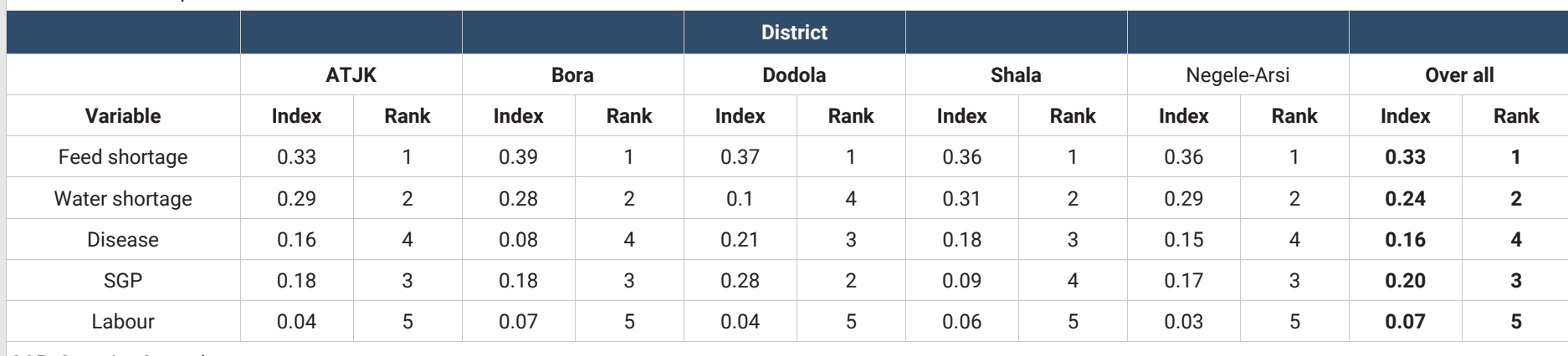

SGP: Superior Germplasm

to commonness in polygamy of which it's an advantage in agrarian activity. In study districts, cattle mainly are reared primarily for draft, milk, savings and income sources. The major production constraints are feed shortage, water scarcity, disease and lack of superior germplasm across the study areas. Forage improvement, water preservation, disease prevention and improving genetic potential of cattle are required to resolve the principal cattle production constraints in order to amend the livelihood of small holder farmers.

\section{Acknowledgments}

The authors are grateful to School of Animal and Range Sciences, College of Agriculture, Hawassa University, for providing research methodology. I am grateful to Oromia Agriculture Research Institute for funding the research. I would like to extend our appreciation to Adami Tulu Agriculture Research Centre for technical support and for enabling us with a conducive working environment in conducting the study.

\section{References}

1. CSA (Central Statistical Authority) (2016/17) Agricultural sampling survey, report on livestock and livestock characteristics for the year 2016/17, Addis Ababa, Ethiopia. 194. Link: https://bit.ly/3n7mCOB

2. Ayeneshet B, Abera M, Wondifraw Z (2018) Reproductive and Productive Performance of Indigenous Dairy Cows under Smallholder Farmers Management System in North. Journal of Fisheries Livestock Production 6. Link: https://bit.ly/39XAmHS

3. Mezgebe G, Gizaw S, Urge M, Chavhan A (2017) Begait cattle production systems and production performances in northern Ethiopia. Int J Life Sci 5 : 506-516. Link: https://bit.ly/379msAJ

4. Terefe E, Dessie T, Haile A, Mulatu W, Mwai O (2012) Husbandry and breeding practices of cattle in Mursi and Bodi pastoral communities in South West Ethiopia. African Journal of Agriculture Research 7: 5986-5994. Link: https://bit.ly/3gzxhPo

5. Mekonnen A, Haile A, Dessie T, Mekasha Y (2012) On farm characterization of Horro cattle breed production systems in W-estern Oromia, Ethiopia. Livestock Research for Rural Development 24. Link: https://bit.ly/3a4IAhl

6. Asrat Ayza, Zelalem Yilma, Ajebu Nurfeta (2013) Characterization of milk production systems in and around Boditti, South Ethiopia. Livestock Research for Rural Development25(10):http://www.Irrd.org/lrrd25/10/ayza25183.htm

7. Haile A, Ayalew W, Kebede N, Diese T, Tegegne A (2011) Breeding strategy to improve Ethiopian Boran cattle for meat and milk production. IPMS (improving productivity and Market success) of Ethiopia Farmers project Working paper No.26. ILRI, Nairobi, Kenya. Link: https://bit.ly/375bbB9
8. Minyahel Tilahun1, Ayana Angassa, Aster Abebe, Alemayehu Mengistu (2016) Perception and attitude of pastoralists on the use and conservation of rangeland resources in Afar Region, Ethiopia Ecological Processes (2016) 5:18 DOI 10.1186/s13717-016-0062-4

9. Kassa G, Bereda A, Eshete T, Bekele A (2017) Fattened cattle marketing systems in Moretna Jiru District, North Shoa Zone of Amhara Regional State, Ethiopia. International journal of livestock production 8: 79-86. Link: https://bit.ly/2JKG05C

10. Olayemi A O (2012) Effects of Family Size on Household Food Security in Osun State, Nigeria. Asian Journal of Agriculture and Rural Development 2: 136-141. Link: https://bit.ly/2K8sIVD

11. Gemechu A (2017) Causes and Effects of Land Size Variation on Smallholder's Farm- Income: The Case of Kombolcha District of East Hararghe, Oromia Ethiopia. Open Access Library Journal 4: 2227. Link: https://bit.ly/37V1B34

12. Worku Z, Tilahun S, Tolemariam T, Jimma W (2016) Assessment of the Prevailing Cattle Fattening Practices in Jimma Zone. Global Veterinaria 17: 105-113. Link: https://bit.ly/2JTeFy2

13. Megersa E, Mengistu A, Asebe G (2017) Opportunity and Constraints of Livestock Feed Resources in Abol and Lare Districts of Gambella Region, Ethiopia. Nutrition and Food Science International Journal 3. Link: https://bit.ly/2Kf3Wh0

14. Lemma $M$, Negesse T, Nurfeta A (2016) Assessment of Feed Resource Availability and Quality in Kedida Gamela District, Southern Ethiopia. International Journal of Environment, Agriculture and Biotechnology 1: 24561878. Link: https://bit.ly/3qJfMAV

15. Garoma S (2014) Reproductive and productive performance of Kereyu Sanga cattle in Fantale District of Oromia Region, Ethiopia. Journal of Cell and Anima Biology 8: 28-33. Link: https://bit.ly/3qM0jjx

16. Duguma B, Tegegne A, Hegde BP (2012) Smallholder Livestock Production System in Dandi District, Oromia Regional State, Central Ethiopia. Global Veterinaria 8: 472-479. Link: https://bit.ly/2W0pHUy

17. Zewdu S, Kassa B, Agza B, Alemu F, Muleta G (2014) Smallholder cattle production systems in Metekel zone, northwest Ethiopia. Research Journal of Agriculture and Environmental Management 3: 151-157. Link: https://bit.ly/341NpEm

18. Bayou E, Haile A, Gizaw S, Mekasha Y (2014) Characterizing husbandry practices and breeding objectives of Sheko cattle owners for designing conservation and improvement strategies in Ethiopia. Livestock Research for Rural Development 26. Link: https://bit.ly/3gC1tJZ

19. Tonamo A, Tamir B, Goshu G, Belete E (2015) Characterization of cattle husbandry practices in Essera Woreda, Dawuro Zone of Southern Ethiopia. African Journal of Agricultural Research 10: 3421-3435. Link: https://bit.ly/3qLZYOf

20. Rea T, Aseffa A, Schelling E, Zinsstang J (2010) Farmers' Perceptions of 
Livestock, Agriculture, and Natural Resources in the Rural Ethiopian Highlands International Mountain Society 30: 381-390. Link: https://bit.ly/3m7LEeX

21. Kebede H, Jimma A, Getiso A, Zelke B (2017) Characterization of Gofa cattle production system, Production and Reproduction. J Fisheries Livest Prod 3: 237. Link: https://bit.ly/37U6v09
22. Dinka H (2013) Reproductive performance of crossbred dairy cows under smallholder condition in Ethiopia. African Journal of Dairy Farming and Milk Production 1: 101-103. Link: https://bit.ly/343EwtT

23. Tesfa A, Garikipati DK (2014) Genetic and non-genetic parameter estimates of dairy cattle in Ethiopia. Journal Animal Feed Resources 4: 83-90. Link: https://bit.ly/3qG4ttn

\section{Discover a bigger Impact and Visibility of your article publication with}

\section{Peertechz Publications}

\section{Highlights}

* Signatory publisher of ORCID

* Signatory Publisher of DORA (San Francisco Declaration on Research Assessment)

* Articles archived in worlds' renowned service providers such as Portico, CNKI, AGRIS, TDNet, Base (Bielefeld University Library), CrossRef, Scilit, J-Gate etc.

* Journals indexed in ICMJE, SHERPA/ROMEO, Google Scholar etc.

- OAI-PMH (Open Archives Initiative Protocol for Metadata Harvesting)

* Dedicated Editorial Board for every journal

* Accurate and rapid peer-review process

* Increased citations of published articles through promotions

* Reduced timeline for article publication

Submit your articles and experience a new surge in publication services (https://www.peertechz.com/submission).

Peertechz journals wishes everlasting success in your every endeavours.

Copyright: @ 2020 Gudeto A, et al. This is an open-access article distributed under the terms of the Creative Commons Attribution License, which permits unrestricted use, distribution, and reproduction in any medium, provided the original author and source are credited. 